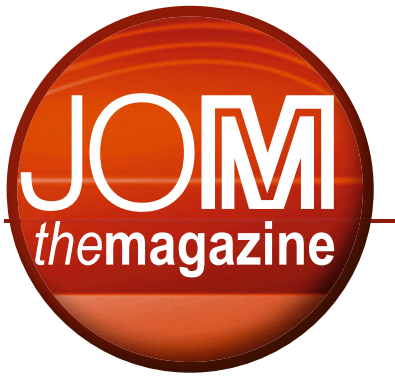

TMS has forged cooperative agreements with several carefully selected organizations that actively work to benefit the materials science community. In this occasional series, JOM will provide an update on the activities of these organizations. This installment, by the Center for Resource Recovery \& Recycling $\left(C R^{3}\right)$, focuses on the different recycling options for electric arc furnace dust and shines a light on a promising new developing technology. The $C R^{3}$ is a research center established by Worcester Polytechnic Institute, Colorado School of Mines, and KU Leuven. More than 20 corporations, along with support from the U.S. National Science Foundation's Industry \& University Cooperative

Research Program, are sponsors of the center.

\section{TMS Partners in Progress}

\section{Moving Towards Better Recycling Options for Electric Arc Furnace Dust}

\section{T. Suetens, K. Van Acker, B. Blanpain, B. Mishra, and D. Apelian}

When recycling steel scrap in an electric arc furnace, $15-18 \mathrm{~kg}$ of dust (EAFD) is generated for each ton of produced steel. This dust essentially is an oxidized mixture of the volatile elements present in the furnace $(\mathrm{Zn}, \mathrm{Pb}$, $\mathrm{Cd}$, and halides) and small steel melt Worldwide, 7.1 Mt of dust were produced in $2010,{ }^{1}$ a number that continues to rise due to increasing recycling volumes and application of galvanization. Since the dust contains the spinel franklinite $\left(\mathrm{ZnFe}_{2} \mathrm{O}_{4}\right)$, recycling requires drastic treatment conditions to recover the zinc.

U.S. Environmental Protection Agency legislation against landfilling the dust has caused an increase in recycling rates since the late 1980s. However, nothing changed in the regions where landfilling has not been restricted. Due to the large amount of dust generation in those regions, only $40 \%$ of the total amount of generated dust is recycled. This leaves a large potential for improvement in zinc recycling.

Since more than $50 \%$ of all used zinc and slag particles ( $\mathrm{Fe}, \mathrm{Cr}, \mathrm{Ca}, \mathrm{Si}, \mathrm{Mg}$ ). goes into galvanizing, ${ }^{2}$ EAFD plays a key role in the life cycle of zinc. The growing awareness of depletion of metal reserves and increasing metal prices are becoming good motivators to start the treatment of the dust in favor of landfilling. In the regions where recycling rates were already good, these extra incentives resulted in a growing interest in the iron content of the dust for iron recovery.

A whole range of metallurgical technologies was developed to recycle the dust. So far, most of these have faced serious problems. For the hydro projects, the stability of the franklinite phase has always been a major issue. Since it does not dissolve under most leaching conditions, a maximum zinc leaching recovery of $70 \%$ has been observed. ${ }^{3}$ Another issue of the hydrometallurgical processes is that they are unable to recover iron economically. With increasing interest of the industry to also recover the iron, the appeal of hydro for further development has been dwindling. High temperature metal recovery (HTMR)

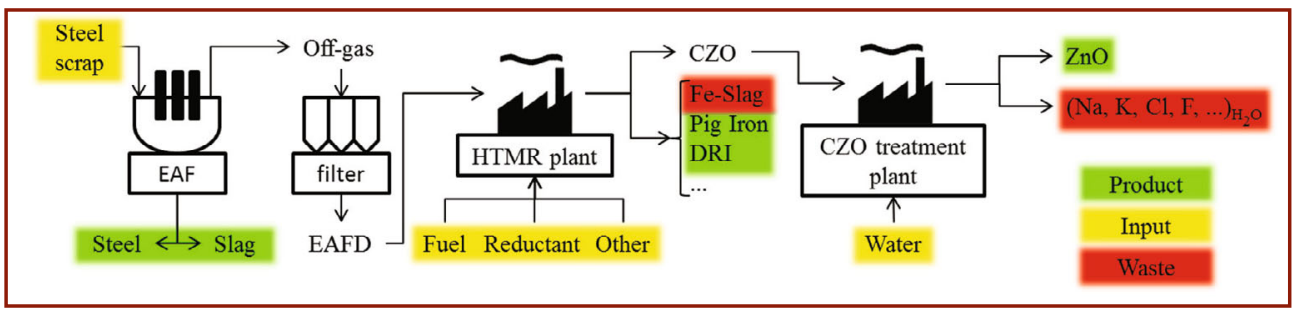

Figure 1. Traditional electric arc furnace dust treatment pathway.

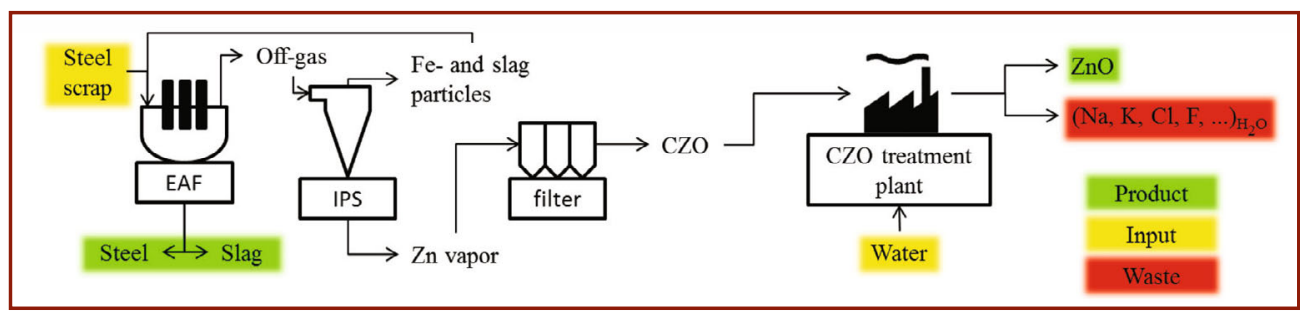

Figure 2. Alternative EAFD treatment pathway. Implementation of IPS could replace the need for an energy and resource intense HTMR process. 
Table I. Overview of Currently Available Recycling Options for Electric Arc Furnace Dust

\begin{tabular}{|c|c|c|c|c|c|c|}
\hline Process Name & Temperature & Furnace type Input & Products & Scale & Capacity & (kt/y) \\
\hline Waelz Kiln 1,4 & $1150-1200^{\circ} \mathrm{C}$ & Rotary kiln & $\begin{array}{l}\text { Coal, lime/sand, } \\
\text { natural gas, air }\end{array}$ & CZO, Fe-slag (waste) & Commercial & $40-250$ \\
\hline $\begin{array}{l}\text { RHF }^{5} \\
\qquad \text { (low Zn EAFD) }\end{array}$ & $1250-1300^{\circ} \mathrm{C}$ & Rotary hearth furnace & $\begin{array}{l}\text { Coke, binder, } \\
\text { natural gas }\end{array}$ & $\mathrm{CZO}, \mathrm{DRI} / \mathrm{HBI}$ & Commercial & $100-300$ \\
\hline $\begin{array}{l}\mathrm{RHF}^{5-9} \\
\quad(\text { high Zn EAFD) }\end{array}$ & $1250-1300^{\circ} \mathrm{C}$ & Rotary hearth furnace & $\begin{array}{l}\text { Coke, binder, } \\
\text { natural gas }\end{array}$ & $\mathrm{CZO}, \mathrm{DRI} / \mathrm{HBI}$ & Commercial $^{*}$ & 200 \\
\hline Primus ${ }^{10,11}$ & $1000-1100^{\circ} \mathrm{C}$ & $\begin{array}{l}\text { Multiple hearth } \\
\text { furnace + EAF }\end{array}$ & Coal, air & CZO, pig iron & Commercial & 100 \\
\hline Ausmelt ${ }^{12-14}$ & $1250-1300^{\circ} \mathrm{C}$ & $\begin{array}{l}\text { Top Submerged } \\
\text { Lance furnace }\end{array}$ & $\begin{array}{c}\text { Coal, } \\
\mathrm{O}_{2} \text {-enriched air }\end{array}$ & $\begin{array}{l}\text { CZO, Fe-slag } \\
\text { (waste) }\end{array}$ & Commercial & 100 \\
\hline $\mathrm{ESRF}^{15,16}$ & $1300-1500^{\circ} \mathrm{C}$ & EAF & $\begin{array}{l}\text { Binder, air, } \\
\text { electricity }\end{array}$ & $\begin{array}{l}\text { CZO, Pig iron, } \\
\text { and slag }\end{array}$ & Commercial & 36 \\
\hline $\begin{array}{l}\text { Submerged } \\
\text { Plasma }^{17-19}\end{array}$ & $1300-1400^{\circ} \mathrm{C}$ & $\begin{array}{l}\text { Submerged plasma } \\
\text { reactor }\end{array}$ & $\begin{array}{l}\text { Coke, natural gas, } \\
\text { fluxes, air, electricity }\end{array}$ & CZO, Fe-slag (waste) & Commercial & $40-60$ \\
\hline $\mathrm{PIZO} 20-22$ & $1300-1500^{\circ} \mathrm{C}$ & Induction furnace & Coal, air, electricity & CZO, pig iron & Commercial & 50 \\
\hline OxiCup ${ }^{23}$ & $1500-1600^{\circ} \mathrm{C}$ & Shaft furnace & $\begin{array}{c}\text { Coke, scrap, bricks } \\
\text { (waste + cement + C) }\end{array}$ & $\begin{array}{c}\text { CZO, molten } \\
\text { metal, and slag }\end{array}$ & Commercial & $\begin{array}{l}200 \text { (dust } \\
\text { and sludge) }\end{array}$ \\
\hline Coke Packed Bed ${ }^{24,25}$ & $1500-1600^{\circ} \mathrm{C}$ & Shaft furnace & $\begin{array}{l}\text { Coke, fluxes, } \\
\mathrm{O}_{2} \text {-enriched air }\end{array}$ & $\begin{array}{l}\text { CZO, molten metal, } \\
\text { and slag }\end{array}$ & Pilot Plant & 10 \\
\hline LAMS $^{26,27}$ & $900-1100^{\circ} \mathrm{C}$ & - & $\mathrm{CaCO}_{3}+$ heat & $\begin{array}{l}\mathrm{CZO}, \mathrm{Ca}_{2} \mathrm{Fe}_{2} \mathrm{O}_{5} \text { for } \\
\text { use in blast furnace }\end{array}$ & Lab-scale & - \\
\hline EAFD+PVC pellets 28,29 & $800^{\circ} \mathrm{C}$ & - & PVC + heat & $\mathrm{ZnCl}_{2}, \mathrm{Fe}+\mathrm{C}$ pellets & Lab-scale & - \\
\hline
\end{tabular}

* First large proof-of-concept plant is still ramping up to full production.

processes, on the other hand, have known a certain degree of success. Currently, the Waelz kiln process is recognized as the best available technique to handle the dust. It is used to treat roughly $80 \%$ of all recycled EAFD. Traditionally, the recycling of EAFD can be seen as described in Fig. 1. As an alternative to the Waelz kiln process, a variety of different technologies have been developed.

These use different furnace designs, working temperatures, reducing agents,

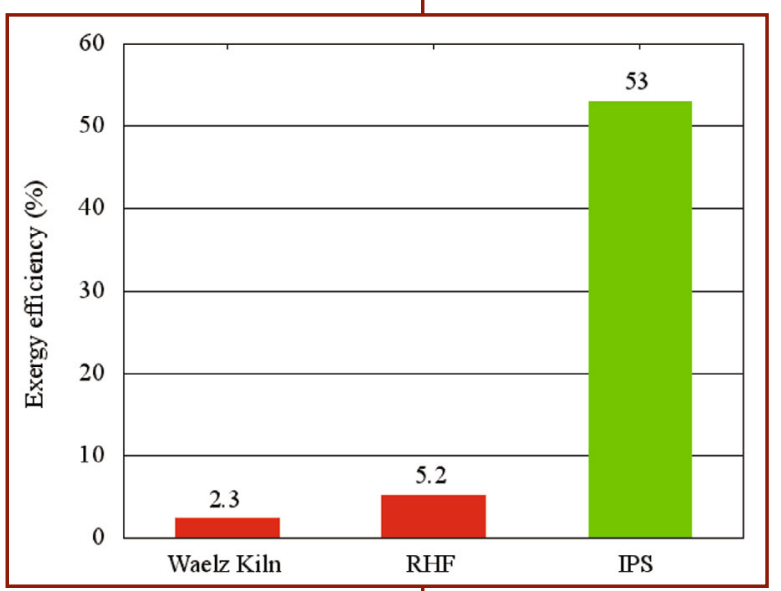
additives, etc. An overview of these alternatives can be found in Table I. Most of these processes produce a crude zinc oxide (CZO) product that requires some further processing (halide removal) before it can be used by zinc smelters.

In a previous

Figure 3. Exergy efficiencies of the Waelz kiln, RHF, and IPS technologies. exergy efficiency analysis study for $\mathrm{CR}^{3}$ the two most applied technologies (Waelz kiln and RHF) have been compared. ${ }^{30}$
Starting from the EAF off-gas, the optimized Waelz kiln process (Table I, first entry) underperforms compared to the RHF process as described by ZincOx (Table I, third entry).

However, this study clearly indicated that HTMR processes might not be the ultimate solution for EAFD recycling since their total exergy efficiencies are rather low. The study also included calculations for a new, conceptual alternative to HTMR processes: treatment of the EAF off-gas in the EAF plant itself to prevent the formation of EAFD and the need for its costly recycling processes.

Recently, N. Ma proposed a radical new approach, the In-Process Separation (IPS) technology, ${ }^{31,32}$ in which zinc is removed from the EAF off-gas before it can react with iron-containing particles to form the $\mathrm{ZnFe}_{2} \mathrm{O}_{4}$ phase in the combustion chamber (Fig. 2). The dust collected in the baghouse filters can then be sent directly to the CZO treatment plant as it will no longer contain Fe. Depending on the atmospheric conditions in the off-gas treatment system, iron or iron oxide particles can be returned to the EAF. Thermodynamically, this treatment step drastically outperforms any HTMR 
process since it has an exergy efficiency of $53 \%$ (Fig. 3) while the exergy efficiency of the current EAF off-gas system is $24 \%$. Further treatment of the dust in a HTMR process will only reduce this value. Economically, the technology would transform the traditional EAF off-gas treatment system from a waste collecting part of the plant to a zero-waste valuable by-product producing segment.

Recognizing the technology's potential impact on EAFD recycling, $\mathrm{CR}^{3}$ has a project running to experimentally evaluate the feasibility of the IPS technology. The major drawback of this new technology is that it requires implementation in each individual EAF plant. Unlike traditional HTMR processes, the starting product cannot be collected from a larger area to treat a lot of dust simultaneously. All plants operating without the IPS technology will continue producing EAFD, maintaining the need for HTMR plants.

\section{References}

1. N.L. Piret, World of Metallurgy - ERZMETALL, 65 (2012), pp. 306-316.

2. International Zinc Association, Durhan, NC, www.zinc. org.

3. N.L. Piret, "Processing of Zinc-bearing Iron- and Steelmaking Residues-An Overview," Short Course Lecture Pb-Zn 2010 (MetSoc-CIM, Vancouver, Canada, 3 October 2010).

4. J. Rütten, C. Frias, G. Diaz, D. Martin, and F. Sanchez, European Metallurgical Conf. Proc. (Clausthal-Zellerfeld: Germany: GDMB eV, 2011), pp. 1673-1688.

5. T. Nakayama and H. Taniishi, "Dust Recycling Technology for Electric Arc Furnace Using RHF,' Nippon Steel

Engineering Technical Review 2, 25-29 (2011).

6. H. Oda, T. Ibaraki, and Y. Abe, "Dust Recycling System by the Rotary Hearth Furnace," Nippon Steel Technical Report 94, 147-152 (2006).

7. C. Peng, F. Zhang, H. Li, and Z. Guo, ISIJ Int., 49, 18741881 (2009).

8. M. Tateishi, H. Fujimoto, T. Harada, and H. Sugitatsu Development of EAF Dust Recycling and Melting

Technology Using the Coal-based FASTMELT® Process.

Direct from Midrex (2008), www.midrex.com/uploads/ documents/Development\%20of\%20EAF\%20Dust\%20 Recycling.pdf.

9. ZincOx Resources plc, Surrey, U.K. 2013. Annual Report \& Accounts 2012, www.zincox.com/default.asp.

10. J.L. Roth, R. Frieden, T. Hansmann, J. Monai, and M.

Solvi, La Revue de Métallurgie, 98, 987-996 (2001).

11. Paul Wurth S.A., 2010. Recycling Technologies, folder.

12. G. Assis, "Emerging Pyrometallurgical Processes for Zinc and Lead Recovery from Zinc-Bearing Waste Materials" (Paper presented at the Zinc and Lead

Processing Symposium, The Metallurgical Society of CIM,
Calgary, Canada, August 1998).

13. J. Hoang, M.A. Reuter, R. Matusewicz, S. Hughes, and N. Piret, Min. Eng., 22, 742-751 (2009).

14. S. Hughes, M.A. Reuter, R. Baxter, and A. Kaye, Proc. Lead and Zinc 2008 (Johannesburg, South Africa: South African Institute of Mining and Metallurgy (SAIMM), 2008), pp. 147-162.

15. N. Nakayama, "New EAF Dust Treatment Process: ESRF" (Yokohama, Japan: JP Steel Plantech Co., 2011), steelplantech.com/wp-content/uploads/2013/11/201105_ EAF_DustTreatment_byNewProcess.pdf.

16. M. Nakayama, "EAF Dust Treatment for High Metal Recovery" (Yokohama, Japan: JP Steel

Plantech Co., 2012), steelplantech.com/wp-content/ uploads/2013/11/201108_EAF_DustTreatment_ forHighMetalRecovery.pdf.

17. V. Popovici, "By-Products from EAF Dust Recycling and Their Valorisation" (Paper presented at the 5th Global Slag Conf., Brussels, Belgium, 23-24 November 2009).

18. ScanArc Commercial plants (ScanArc Plasma Technologies AB, Hofors, Sweden), www.scanarc.se/ pages. asp?PagelD=4285.

19. K. Verscheure, M. Van Camp, B. Blanpain, P. Wollants, P. Hayes, and E. Jak, Metall. Mater. Trans. B, 38B, 21-33 (2007).

20. J.E. Bratina and K.M. Lenti, "PIZO Furnace

Demonstration Operation For Processing EAF Dust" (Warrendale, PA: AIST, May 2007).

21. "UPDATE: "Substantial" Damage from Pizo Fire," Blytheville Courier News (25 July 2011). www.couriernews. net/story/1747211.html.

22. "PIZO History" (PIZO, Indianapolis, IN), pizotech.com/ about/index.html.

23. C. Bartels-von Varnbüler, M. Lemperle, and H.J. Rachner, "Recovery of Iron from Residues Using the OxiCup Technology" (MPT International 1/2006, Küttner GmbH \& Co KG, 2006), pp. 18-27.

24. Y. Hara, N. Ishiwata, H. Itaya, and T. Matsumoto, ISIJ Int., 40 (2000), pp. 231-237.

25. H. Itaya, Kawasaki Steel Giho, 31 (1999), pp. 1-7.

26. K. Nakajima, K. Matsubae-Yokoyama, S. Nakamura, S. Itoh, and T. Nagasaka, ISIJ Int., 48 (2008), pp. 1478-1483. 27. S. Itoh, A. Tsubone, K. Matsubae-Yokoyama, K. Nakajima, and T. Nagasaka, ISIJ Int., 48 (2008), pp. 1339-1344.

28. G.-S. Lee and Y.J. Song, Min. Eng., 20 (2007), pp. 739-746.

29. J. Wichterlová, R. Skuta, M. Metzing, D. Matýsek, and K. Wichterle, "Simultaneous Thermal Decomposition of PVC and Zinc Ferrite" (Paper presented at the $36^{\text {th }}$ Int. Conf. SSCHE, Tatranské Matliare, Slovakia, 25-29 May 2009). 30. T. Suetens, B. Klaasen, K. Van Acker, and B. Blanpain, J. Cleaner Production, 65 (2014), pp. 152-167.

31. N.-Y. Ma, EPD Congress 2011, ed. S.N. Monteiro, P.N. Anyalebechi, D.E. Verhulst, and J.A. Pomykala (Warrendale, PA: TMS, 2011), pp. 947-952.

32. N.-Y. Ma, "Apparatus and Method for Treating Exhaust Gas," U.S. patent 8,377,175 (19 February 2013).

T. Suetens, K. Van Acker, and B. Blanpain are with KU Leuven, University of Leuven, Leuven, Belgium; B. Mishra is with Colorado School of Mines, Golden, CO, USA; and D. Apelian is with the Metal Processing Institute, Worcester Polytechnic Institute, Worcester, MA, USA. For more information, contact D. Apelian at dapelian@wpi.edu. 